\title{
A SEA CHANGE IN THE LAW OF CONTRACT INTERPRETATION?
}

\author{
David McLauchlan*
}

This article challenges the recent extrajudicial argument of Sir Geoffrey Vos, Chancellor of the High Court of England and Wales, that there has been a "distinct sea change" in the law of contract interpretation as a result of the United Kingdom Supreme Court's decisions in Rainy Sky SA v Kookmin Bank, Arnold v Britton and Wood v Capita Insurance Services Ltd. He suggests that these decisions have the effect that Lord Hoffmann's well-known restatement of the law in Investors Compensation Scheme Ltd v West Bromwich Building Society, particularly his Lordship's fourth and fifth principles, no longer represent the law. In his view, the position now is that a court must give the words of a contract their plain meaning except "in a most exceptional case or a case of obvious absurdity". However, Professor McLauchlan argues that Sir Geoffrey reads more into the decisions than is warranted by the Supreme Court's reasoning and that Lord Hoffmann's restatement has survived largely unscathed. In substance, the reasoning spelt out what was either explicit or implicit in the restatement in the first place.

\section{INTRODUCTION}

When I completed two recent articles on the subject of contract interpretation, ${ }^{1}$ I resolved that they should, indeed must, be my last words on the subject. But, as often happens in life, such resolutions weaken over time! On this occasion the weakness was brought about by continuing suggestions that Lord Hoffmann's famous restatement of the principles of contract interpretation in Investors Compensation Scheme Ltd $v$ West Bromwich Building Society $(I C S)^{2}$ can no longer be taken as representing the law, at least not wholly so. Thus, in October 2017 Sir Geoffrey Vos (Vos), Chancellor of the High Court of England and Wales, gave a lecture, subsequently published in the

* Professor of Law, Victoria University of Wellington; Professorial Fellow, The University of Melbourne; and Honorary Professor, The University of Queensland.

1 David McLauchlan "Some fallacies concerning the law of contract interpretation" [2017] LMCLQ 506; and David McLauchlan "Contract Interpretation and Deleted Words: A Not So Pleasant Diversity of Authority" (2018) 35 JCL 90.

2 Investors Compensation Scheme Ltd v West Bromwich Building Society [1998] 1 WLR 896 (HL) [ICS] at 912-913. 
Canterbury Law Review, ${ }^{3}$ in which he said that "there has been a distinct sea change in the law since the House of Lords decided [ICS] in June 1997". ${ }^{4}$ Despite this change having been "repeatedly denied or at least played down", principally by "judges at the highest level [who] have not always said exactly what they mean", it was "palpable", so much so that he was prepared to question whether "ICS would itself be decided the same way if it came to the UK Supreme Court today". ${ }^{5}$ The change was felt "particularly strongly" by Vos since he was counsel for the successful appellants in ICS, after "having had [his] case rather ridiculed by the Court of Appeal". ${ }^{6}$ Interestingly, further reflection on the subject has apparently not altered his view because, less than a year later in September 2018, he gave another lecture, this time on the broader topic of recent developments in the common law, which he introduced by asserting, seemingly with even greater confidence, that "the law on contractual interpretation as laid down in [ICS has] not survived the two recent UK Supreme Court decisions in Arnold v Britton and Wood v Capita". ${ }^{7}$

In this article I propose to challenge the author's view and the reasons given in support of it. Leaving to one side his points concerning the related topics of rectification and implication of terms, three main arguments were made. First, the initial signal of a departure from the ICS principles came in Lord Clarke's "seminal judgment"8 in Rainy Sky SA v Kookmin Bank. ${ }^{9}$ Secondly, the departure "prefaced in Rainy Sky" was "taken forward"10 in Arnold v Britton. ${ }^{11}$ Thirdly, the Supreme Court in

3 Geoffrey Vos "Contractual Interpretation: Do Judges Sometimes Say One Thing and Do Another?" (2017) 23 Canta LR 1.

4 At 2 .

5 At 2 .

6 At 2 .

7 Geoffrey Vos, Chancellor of the High Court "Certainty v Creativity: Some pointers towards the development of the common law" (SAL Distinguished Speaker Lecture, Singapore Academy of Law, Singapore, 14 September 2018). A similar view has recently been expressed by United Kingdom Supreme Court Judge Lord Sales in the course of his Chancery Bar Association lecture "Fraud on a Power: the interface between contract and equity" (Lincoln's Inn, London, 2 April 2019). The Judge referred to "[t]he recent re-affirmation of a fairly strict semantic approach to the interpretation of contracts in Arnold v Britton". In his view:

The tendency under the interpretive approach set out in the Investors Compensation Scheme case for contract terms to be construed with an emphasis on reasonable understanding, presumably judged in the light of the circumstances thrown up by the dispute in hand, has been curtailed ...

and a "more narrowly semantic approach" adopted.

8 Vos, above n 3, at 5.

9 Rainy Sky SA v Kookmin Bank [2011] UKSC 50, [2011] 1 WLR 2900 [Rainy Sky (SC)].

10 Vos, above n 3, at 6.

11 Arnold v Britton [2015] UKSC 36, [2015] AC 1619. 
Wood v Capita $^{12}$ endorsed Rainy Sky and Arnold v Britton "in such a way as to make clear that there is no room in the current law for the fourth and fifth principles stated in $I C S^{\prime \prime} .{ }^{13}$ It was therefore concluded that the law is: ${ }^{14}$

... now as clear as can be that contractual interpretation is limited to choosing between two available meanings of the words used and that there is not, save anyway in a most exceptional case or a case of obvious absurdity, any scope for adjusting the language to reflect what the objective observer would think the parties must actually have meant in the light either of the other terms of the written contract or the available factual matrix.

If these arguments are well founded, it would indeed follow that Vos is justified in questioning whether ICS, where the words "any claim sounding in rescission (whether for undue influence or otherwise)" were substituted for "any claim (whether sounding in rescission for undue influence or otherwise)", could be decided the same way today. This is because, although the majority of their Lordships did not dispute the view of the dissenting Judge that the consequences of the literal interpretation fell short of being absurd, they held that this interpretation was not what the parties in the light of the relevant background could reasonably be understood to have meant.

\section{WHAT DID RAINY SKY DECIDE?}

It is surprising that Lord Clarke's judgment in Rainy Sky should be described as "seminal" because, as explained at length elsewhere, ${ }^{15}$ it contains a number of inconsistencies or mixed messages that make it difficult to know what his Lordship intended to say. The suggestion by Vos that the case heralded a departure from the ICS principles is based on the following passage in the judgment: ${ }^{16}$

The language used by the parties will often have more than one potential meaning. I would accept the submission made on behalf of the appellants that the exercise of construction is essentially one unitary exercise in which the court must consider the language used and ascertain what a reasonable person, that is a person who has all the background knowledge which would reasonably have been available to the parties in the situation in which they were at the time of the contract, would have understood the parties to have meant. In doing so, the court must have regard to all the relevant surrounding circumstances. If there are two possible constructions, the court is entitled to prefer the construction which is consistent with business common sense and to reject the other.

12 Wood v Capita Insurance Services Ltd [2017] UKSC 24, [2017] AC 1173.

13 Vos, above n 3, at 7.

14 At 11

15 David McLauchlan and Matthew Lees "More Construction Controversy" (2012) 29 JCL 97 at 110-120.

16 Rainy Sky (SC), above n 9, at [21] (emphasis added by Vos, above $\mathrm{n} 3$, at 5). 
The reliance on this passage came as a surprise to me because I had cited it as one of a number of indications that Lord Clarke actually endorsed and applied the ICS principles! ${ }^{17}$ I saw it as complementing the following statement by his Lordship at the beginning of his analysis of the principles of interpretation: ${ }^{18}$

... the ultimate aim of interpreting a provision in a contract, especially a commercial contract, is to determine what the parties meant by the language used, which involves ascertaining what a reasonable person would have understood the parties to have meant. As Lord Hoffmann made clear in the first of the principles he summarised in the Investors Compensation Scheme case ... the relevant reasonable person is one who has all the background knowledge which would reasonably have been available to the parties in the situation in which they were at the time of the contract.

Significantly too, this passage was preceded by a citation, and implicit endorsement, of Lord Hoffmann's reasoning in paragraphs [21]-[26] of his judgment in Chartbrook v Persimmon Homes Ltd (Chartbrook) which included the following statement: ${ }^{19}$

What is clear from these cases is that there is not, so to speak, a limit to the amount of red ink or verbal rearrangement or correction which the court is allowed. All that is required is that it should be clear that something has gone wrong with the language and that it should be clear what a reasonable person would have understood the parties to have meant.

Vos, on the other hand, regards the passage he quotes as introducing "a two-step approach - first, identifying what constructions of the actual words are possible, then secondly identifying which of the identified possible constructions is most consistent with business common sense". ${ }^{20}$ In his view: ${ }^{21}$

17 McLauchlan and Lees, above n 15, at 112.

18 Rainy Sky (SC), above n 9, at [14].

19 Chartbrook Ltd v Persimmon Homes Ltd [2009] UKHL 38, [2009] AC 110. See also Lord Clarke's approval (at [25]) of Lord Steyn's observation in Society of Lloyd's v Robinson [1999] 1 WLR 756 (HL) at 763 (emphasis added):

Loyalty to the text of a commercial contract, instrument, or document read in its contextual setting is the paramount principle of interpretation. But in the process of interpreting the meaning of the language of a commercial document the court ought generally to favour a commercially sensible construction. The reason for this approach is that a commercial construction is likely to give effect to the intention of the parties. Words ought therefore to be interpreted in the way in which a reasonable commercial person would construe them. And the reasonable commercial person can safely be assumed to be unimpressed with technical interpretations and undue emphasis on niceties of language.

20 Vos, above n 3, at 5.

21 At 5 (footnote added). 
This formulation seems somewhat to bypass Lord Hoffmann's decision in ICS which adopted a construction that was not a possible construction, and his decision in [Mannai Investment Co Ltd v Eagle Star Life Assurance Co Ltd ${ }^{22}$ ], where it was not possible, anyway, as a matter of the words used, to construe the termination notice as taking effect on 13 January, when it said it took effect on 12 January. In neither case was the result that was achieved by the drafting absurd, just uncommercial.

The corollary of this, as he later observes, is that "there is no room in the current law for the fourth and fifth principles stated in $I C S^{\prime \prime} .^{23}$ It will be recalled that those two principles state: ${ }^{24}$

The meaning which a document (or any other utterance) would convey to a reasonable man is not the same thing as the meaning of its words. The meaning of words is a matter of dictionaries and grammars; the meaning of the document is what the parties using those words against the relevant background would reasonably have been understood to mean. The background may not merely enable the reasonable man to choose between the possible meanings of words which are ambiguous but even (as occasionally happens in ordinary life) to conclude that the parties must, for whatever reason, have used the wrong words or syntax: see Mannai Investment Co Ltd v Eagle Star Life Assurance Co Ltd [1997] AC 749.

The "rule" that words should be given their "natural and ordinary meaning" reflects the common sense proposition that we do not easily accept that people have made linguistic mistakes, particularly in formal documents. On the other hand, if one would nevertheless conclude from the background that something must have gone wrong with the language, the law does not require judges to attribute to the parties an intention which they plainly could not have had.

For several reasons, Vos's statements read much more into the quoted passage than is warranted, either by the passage itself or the remainder of Lord Clarke's judgment. First, it is not clear that his Lordship referred to situations where the parties' language has more than one potential meaning because he believed that only then does the court have a real choice as to the meaning to be attributed to the language. It is unlikely that when he said "[i]f there are two possible constructions"25 he meant "if" in the sense of "only if" as opposed to "where" or "when". It was common ground in the case that the words in dispute were reasonably capable of two meanings and therefore it is understandable that the Judge should address his remarks to that scenario. Indeed, the issue in the case was whether a court must give effect to the "most natural" of the two plausible meanings unless, in the words of Patten LJ in the Court of Appeal, that meaning "produces a result which is so extreme as to suggest that it was unintended". ${ }^{26}$ Lord Clarke gave a negative answer. He ruled that the true principle is that

22 Mannai Investment Co Ltd v Eagle Star Life Assurance Co Ltd [1997] AC 749 (HL) [Mannai Investment].

23 Vos, above n 3, at 7

24 ICS, above n 2, at 913.

25 Rainy Sky (SC), above n 9, at [21].

26 Kookmin Bank v Rainy Sky SA [2010] EWCA Civ 582, [2010] 1 CLC 829 [Rainy Sky (CA)] at [42]. 
"where a term of a contract is open to more than one interpretation, it is generally appropriate to adopt the interpretation which is most consistent with business common sense". ${ }^{27}$ If he had intended to depart in any important respect from the ICS principles he would surely have said so. It is unlikely that he overlooked the fact that, as Lord Hoffmann confirmed in Chartbrook, ICS decided not only that "it was not necessary to find an 'ambiguity' before one could have any regard to background", ${ }^{28}$ but also that: ${ }^{29}$

... the meaning which the parties would reasonably be taken to have intended could be given effect despite

the fact that it was not, according to conventional usage, an "available" meaning of the words or syntax which they had actually used. ${ }^{30}$

Secondly, the statement that Rainy Sky introduced "a two-step approach", with the first step being to identify whether the words in question are capable of bearing more than one meaning is inconsistent with Lord Clarke's acceptance of the proposition that contract interpretation is a "unitary exercise". ${ }^{31}$ The latter term, which is sometimes referred to as the "single task of interpretation", 32 means that there is one step, not two. The document, its context and the commercial consequences of the rival contentions are indispensable and inseparable components of the interpretation process. One does not ask whether the words in dispute have a particular meaning and then ask whether that meaning is displaced by the context. ${ }^{33}$ Neither is a ruling that an interpretation alleged by one party, such as the appellants' interpretation in ICS, is not an available meaning of the words determinative of the outcome, thus in effect rendering consideration of the factual background otiose. Of course, adoption of a unitary approach does not preclude the court beginning its analysis of the issue with a

27 Rainy Sky (SC), above n 9, at [30].

28 Chartbrook, above n 19, at [37].

29 At [37] (footnote added).

30 For this reason it is unlikely that Lord Clarke intended to embrace the old plain meaning rule when he said (at [23]) that "[w]here the parties have used unambiguous language, the court must apply it". This statement, which, surprisingly, was not relied on by Vos, caused much confusion in the cases decided shortly after Rainy Sky. Several took the statement at face value and said that where the words in dispute have a plain meaning there is no scope for giving them a "commercial" or "businesslike" construction. Others suggested that a finding of plain meaning can only be made after consideration of the whole context. Yet another view was that a plain meaning can be displaced only where the absurdity or "commercial nonsense" threshold is met. See David McLauchlan "The lingering confusion and uncertainty in the law of contract interpretation" [2015] LMCLQ 406 at $427-430$.

31 Rainy Sky (SC), above n 9, at [21].

32 Chartbrook, above n 19, at [24].

33 As Lord Hoffmann said in Charter Reinsurance Co Ltd v Fagan [1997] AC 313 (HL) at 392, "[i]t is artificial to start with an acontextual preconception about the meaning of the words and then see whether that meaning is somehow displaced". 
consideration of whether the words have an ordinary meaning. The words used are invariably the starting point of the interpretative task but they cannot ever be the end point. ${ }^{34}$

Having said that, it is not altogether clear whether Vos's position is that the existence of an available meaning is to be determined before or only after resort to the factual background. If it were the former, it would herald a return to the traditional approach to interpretation ${ }^{35}$ under which: (a) the terms of a written contract must be given their plain meaning unless that would result in an absurdity or commercial nonsense; (b) if it is alleged that the parties chose the wrong words to give effect to their intention, the appropriate course is to seek rectification; and (c) only where the words of a contract are ambiguous, or their application to the facts uncertain, is it appropriate to engage in the task of determining which of the competing interpretations is to be preferred in the light of the factual matrix. It is unlikely that the Judge was arguing that there has been a return to this approach because at no stage does he suggest that the courts have rejected Lord Hoffmann's first principle in ICS that interpretation involves ascertaining the meaning that the document would convey to a reasonable person with knowledge of the background. It would certainly be inconsistent with that principle to insist on a preliminary finding of ambiguity before it is permissible to have regard to evidence of the factual background. ${ }^{36}$ Rather it seems that Vos's main contention is that the fourth and fifth ICS principles have been rejected.

This raises the third difficulty with Vos's argument. One cannot sensibly excise the fourth and fifth principles and leave the remainder of the restatement intact because those principles are central to Lord Hoffmann's explanation, and integral to an understanding, of the first principle. Rejection of them would undermine the whole theory on which the restatement was based. Indeed, if it is true that an alleged interpretation must be an "available meaning" of the words in question unless there are

34 Compare the following statement by Tipping $\mathrm{J}$ in Vector Gas Ltd v Bay of Plenty Energy Ltd [2010] NZSC 5 , [2010] 2 NZLR 444 (footnotes omitted) (endorsed recently in The Malthouse Ltd v Rangatira Ltd [2018] NZCA 621 at [22]):

In some recent cases it has been suggested that contractual context should be referred to as a "crosscheck". In practical terms this is likely to be what happens in most cases. Anyone reading a contractual document will naturally form at least a provisional view of what its words mean, simply by reading them. That view is, in a sense, then checked against the contractual context. This description of the process is valid, provided the initial view is provisional only and the reader is prepared to accept that the provisional meaning may be altered once context has been brought to account. The concept of cross-check is helpful in affirming the point made earlier that a meaning which appears plain and unambiguous on its face is always susceptible to being altered by context, albeit that outcome will usually be difficult of achievement.

35 That is, the approach to interpretation that prevailed in the common law courts throughout the 19th century and for much of the 20th.

36 As Lord Steyn pointed out in $R$ (on the application of Westminster City Council) v National Asylum Support Service [2002] UKHL 38, [2002] 1 WLR 2956 at [5], in ICS "Lord Hoffmann made crystal clear that an ambiguity need not be established before the surrounding circumstances may be taken into account". 
wholly exceptional circumstances, the first principle would become an empty shell because the fundamental distinctions on which the principle is premised are discarded. The focus of the interpretative inquiry would inevitably be the meaning of the words, contrary to Lord Hoffmann's instruction that we must not "confuse the meaning of words with the question of what meaning the use of the words was intended to convey". ${ }^{37}$ In his Lordship's view, it is important: ${ }^{38}$

... to distinguish between the meanings of words and the question of what would be understood as the meaning of a person who uses words. The meaning of words, as they would appear in a dictionary, and the effect of their syntactical arrangement, as it would appear in a grammar, is part of the material which we use to understand a speaker's utterance. But it is only a part; another part is our knowledge of the background against which the utterance was made. It is that background which enables us, not only to choose the intended meaning when a word has more than one dictionary meaning but also, in the ways I have explained, to understand a speaker's meaning, often without ambiguity, when he has used the wrong words.

Thus, an alleged plain meaning will be displaced where the words would have conveyed a different meaning to a reasonable person with knowledge of the background.

Finally, aside from the ratio in Rainy Sky mentioned earlier that, where there are competing arguable interpretations of a contract, the court is entitled to prefer the one that is more consistent with business common sense over the "most natural" one, the true significance of the decision is that it illustrates how the meaning a reasonable person will attribute to disputed language will vary according to how one balances internal textual considerations and external factors. For example, depending on the strength of the textual considerations, sometimes it may be necessary to categorise the consequence of the rejected interpretation as absurd, rather than merely unreasonable. This largely accounts for the different conclusions of the Court of Appeal and the Supreme Court in Rainy Sky. In order to explain this point, we need to consider the facts in some detail.

The case concerned the proper interpretation of advance payment bonds issued by the defendant bank to each of six claimants who had entered into contracts to buy ships from a Korean shipbuilder on terms requiring payment of the price by instalments at specified times. After instalments had been paid the shipbuilder experienced financial difficulties and became subject to a debt workout procedure. This insolvency event entitled the buyers to demand an immediate refund of their instalments. Demands were made but declined, whereupon the buyers sought repayment from the bank. On the surface they had an open-and-shut claim because paragraph 3 of each bond stated: ${ }^{39}$

37 Mannai Investment, above n 22, at 779.

38 At 775

39 Rainy Sky (SC), above n 9, at [7] (emphasis added). 
In consideration of your agreement to make the pre-delivery instalments under the [building] contract ... we hereby, as primary obligor, irrevocably and unconditionally undertake to pay to you, your successors and assigns, on your first written demand, all such sums due to you under the contract ...

However, the bank relied on the immediately preceding paragraph 2 of each bond that stated: ${ }^{40}$

Pursuant to the terms of the contract, you are entitled, upon your rejection of the vessel in accordance with the terms of the contract, your termination, cancellation or rescission of the contract or upon a total loss of the vessel, to repayment of the pre-delivery instalments of the contract price paid by you prior to such termination or a total loss of the vessel ...

It was argued that the expression "such sums" in paragraph 3 was a reference to the sums described in paragraph 2, namely, the pre-delivery instalments paid prior to a termination of the contract or a total loss of the vessel, and hence the bond did not cover the builder's insolvency, which was not an event giving the buyers a right to cancel. The buyers, on the other hand, argued that "such sums" referred back to "the pre-delivery instalments" in the first line of paragraph 3 so that the bonds guaranteed repayment of pre-delivery instalments in all instances where the builder breached its refund obligation. This interpretation was upheld at first instance by Simon J who ruled that the bank's interpretation: ${ }^{41}$

... has the surprising and uncommercial result that the buyers would not be able to call on the bond on the

happening of the event which would be most likely to require the first class security.

A majority of the Court of Appeal disagreed, ${ }^{42}$ but Simon J's decision was reinstated by a unanimous Supreme Court in the judgment delivered by Lord Clarke. ${ }^{43}$

In the Court of Appeal Patten LJ held that the competing interpretations, which were primarily based on the wording of the bonds and the shipbuilding contract, were not "in any way evenly balanced". ${ }^{44}$ The buyer's interpretation was not "the meaning which the document would convey to a reasonable person reading it with knowledge of the terms of the shipbuilding contract". ${ }^{45}$ Although security for repayment in the event of insolvency "was, objectively speaking, desirable", it was not "the natural and obvious construction of the bond". ${ }^{46}$ Furthermore, that construction did not "produce

40 At [7].

41 Rainy Sky SA v Kookmin Bank [2009] EWHC 2624 (Comm) [Rainy Sky (HC)] at [18(iii)].

42 Rainy Sky (CA), above n 26 (Patten and Thorpe LJJ, Sir Simon Tuckey dissenting).

43 With whom Lord Phillips, Lord Mance, Lord Kerr and Lord Wilson agreed.

44 Rainy Sky (CA), above n 26, at [51]

45 At [50].

46 At [51]. 
an absurd or irrational result". ${ }^{47}$ Importantly for present purposes, there is nothing in his Lordship's judgment to suggest that, if the competing interpretations had been seen as more evenly balanced, so that the bond was reasonably capable of either meaning, he would have thought it inappropriate to favour the more commercial interpretation. Having in effect found that there was an absence of "any real ambiguity in the language of the bond" ${ }^{48}$ his primary objection to the conclusion that the buyers should have the objectively desirable security for insolvency was that this would, on the basis of the evidence before the Court, be to grant relief from a bad bargain. It would rewrite not the language, but the bargain itself. A court is not entitled to reformulate "relatively clear" contractual provisions "simply because" those provisions "balance the interests and obligations of the parties in a way which the judge considers to be one-sided or unfair". ${ }^{4}$

In the Supreme Court, however, Lord Clarke took a wholly different view of the merits of the parties' arguments. His Lordship disagreed that the bank's interpretation represented "the natural and ordinary meaning of the bonds".$^{50}$ In his view, the competing arguments were "much more finely balanced than suggested by Patten LJ and the bank". ${ }^{51}$ Indeed, he said that if the case were to be decided solely on the basis of textual analysis he "would be inclined to prefer the buyers' construction to that of the bank". ${ }^{52}$ However, since the relevant language was reasonably capable of two meanings, it was "appropriate for the court to have regard to considerations of commercial common sense in resolving the question what a reasonable person would have understood the parties to have meant"53 and, as we have seen, his Lordship ruled in favour of the buyers because their interpretation was more consistent with business common sense than the bank's interpretation. In summary, therefore, Rainy Sky was a case where the Court of Appeal and Supreme Court Judges asked essentially the same question - what meaning would the terms of the bonds convey to a reasonable person with knowledge of the background - but reached different conclusions stemming from different readings of the relevant terms.

It remains to note that Vos is not the only commentator to misinterpret Rainy Sky. Thus, in a provocative recent extra-judicial speech that contains severe criticisms of the ICS principles ${ }^{54}$ Lord

47 At [51].

48 At [36].

49 At [41].

50 Rainy Sky (SC), above n 9, at [34].

51 At [35].

52 At [40].

53 At [40].

54 Lord Sumption "A question of taste: the Supreme Court and the interpretation of contracts" (2017) 17 OUCLJ 301. 
Sumption argued that that the Court overrode "the apparent meaning of the contract" that favoured the respondent bank on the basis that the appellants' interpretation was more reasonable and therefore the apparent meaning "did not really represent the parties' intentions". ${ }^{55}$ This overlooks the fact that Lord Clarke rejected the plain meaning alleged by the bank. As mentioned above, his Lordship said that, if the case had to be decided on the basis of the language of the document without regard to considerations of commercial common sense, he would have preferred the buyers' construction.

An even more surprising misunderstanding of Rainy Sky is to be found in the Scottish Law Commission's recent review of aspects of the law of contract. ${ }^{56}$ The Commission wrongly describes the case as one where there was "no linguistic ambiguity" because "[t]he bonds simply did not include the shipbuilder's insolvency as a triggering event". ${ }^{57}$ In its view, the issue was "whether or not business common sense could be invoked to insert what was effectively an additional clause into the bond". ${ }^{58}$ Of course, as discussed above, the actual language of the bond provided ample basis for a conclusion that the bonds did cover pre-delivery instalments that were not refunded by the shipbuilder due to its insolvency.

\section{DID ARNOLD V BRITTON CHANGE THE LAW?}

As mentioned earlier, Vos contends that the alleged departure from ICS in Rainy Sky was "taken forward" in Arnold v Britton. ${ }^{59}$ That is not so. It is certainly true that the judgment of Lord Neuberger (with which Lord Sumption and Lord Hughes agreed) contains statements suggesting that courts should not lightly depart from the "natural and ordinary meaning" of the language in dispute and that interpretation disputes should ordinarily be resolved on the basis of textual analysis with limited resort to external context. However, nothing is said that is necessarily inconsistent with ICS principles. That was certainly the understanding of the English Court of Appeal in several cases decided soon after Arnold v Britton. Thus, in Globe Motors Inc v TRW Lucas Varity Electric Steering Ltd ${ }^{60}$ Beatson LJ said that "[t]he formulations by appellate judges have differed, but the differences have primarily been

55 At 308

56 Scottish Law Commission Report on Review of Contract Law: Formation, Interpretation, Remedies for Breach, and Penalty Clauses (SCOT LAW COM No 252, March 2018).

57 At [8.4]

58 At [8.4]. The Commission concluded at [8.9]:

Rainy Sky is perhaps the clearest example of commercial common sense being used in ... a purposive manner as, on a purely linguistic level, there was no ambiguity in the words used. It was only after one considered the purpose of the transaction that the omission of the shipbuilder's insolvency seemed strange.

59 Vos, above n 3, at 6.

60 Globe Motors Inc v TRW Lucas Varity Electric Steering Ltd [2016] EWCA Civ 396, [2017] 1 All ER (Comm) 601. 
ones of emphasis rather than of principle"61 and that in Arnold $v$ Britton "the change of emphasis was to give greater weight to the words used in the document". ${ }^{62}$ And in Transocean Drilling UK Ltd v Providence Resources plc ${ }^{63}$ Moore-Bick LJ regarded Arnold as having simply "re-emphasised" the importance of "the language chosen by the parties to express their intentions". ${ }^{64}$ These observations are not surprising since the core elements of the principles were in fact expressly endorsed by Lord Neuberger. Thus, his Lordship began his analysis of the law in the following passage that is not cited by Vos: 65

When interpreting a written contract, the court is concerned to identify the intention of the parties by reference to "what a reasonable person having all the background knowledge which would have been available to the parties would have understood them to be using the language in the contract to mean", to quote Lord Hoffmann in Chartbrook Ltd v Persimmon Homes Ltd [2009] AC 1101, para 14. And it does so by focusing on the meaning of the relevant words ... in their documentary, factual and commercial context. That meaning has to be assessed in the light of (i) the natural and ordinary meaning of the clause, (ii) any other relevant provisions of the [contract], (iii) the overall purpose of the clause and the [contract], (iv) the facts and circumstances known or assumed by the parties at the time that the document was

61 At [56].

62 At [58]. See also his Lordship's observation in Evangelou v McNicol [2016] EWCA Civ 817 at [22] that in Arnold "the majority of the Supreme Court adjusted the balance between the words of the contract and its context and background by giving greater weight to the words used". But compare Gerard McMeel McMeel on the Construction of Contracts: Interpretation, Implication, and Rectification (3rd ed, Oxford University Press, Oxford, 2017) at [1.79] (arguing that even this alleged change of emphasis is "over-stated" and inconsistent with "the actual results in a significant number of cases including decisions of the [UK] Supreme Court").

63 Transocean Drilling UK Ltd v Providence Resources plc [2016] EWCA Civ 372, [2016] 2 All ER (Comm) 606.

64 At [14]. See also TJH and Sons Consultancy Ltd v CPP Group plc [2017] EWCA Civ 46 at [10]-[11]; Irish Bank Resolution Corp Ltd (in special liq) v Camden Market Holdings Corp [2017] EWCA Civ 7, [2017] 2 All ER (Comm) 781 at [29]; Credit Suisse Asset Management LLC v Titan Europe 2006-1 plc [2016] EWCA Civ 1293 at [23]-[28]; and Spar Shipping AS v Grand China Logistics Holding (Group) Co Ltd [2016] EWCA Civ 982, [2017] 4 All ER 124 at [58] per Gross LJ ("it would be quite wrong to overlook commercial common sense, even recognising that its claims can be over-stated and its application vulnerable to the particular perspective of the party espousing them"). Compare, however, Savills (UK) Ltd v Blacker [2017] EWCA Civ 68 at [33] where Patten LJ left open:

... the question whether and, if so, how far the pendulum has swung in relation to Lord Hoffmann's view that the normal or dictionary meaning of the words used must always yield to context ...

although his Lordship still considered it relevant to ask "whether the natural and ordinary meaning of the language used produces a commercially unlikely result".

65 Arnold, above n 11, at [15]. 
executed, and (v) commercial common sense, but (vi) disregarding subjective evidence of any party's intentions.

It is difficult to see anything in this passage that Lord Hoffmann, based on his leading judgments, would disagree with.

It is significant too that Lord Neuberger expressly agreed with the reasons given by Lord Hodge. ${ }^{66}$ The latter accepted that Lord Hoffmann's first ICS principle involves a unitary process of interpretation ${ }^{67}$ and he also endorsed, as indeed did Lord Clarke in Rainy Sky, ${ }^{68}$ the common description of it as involving "an iterative process by which each of the rival meanings is checked against the provisions of the contract and its commercial consequences are investigated". 69

However, in expressing the contrary view, Vos relies on Lord Neuberger's description of various factors to be borne in mind when applying the principle in the above quoted passage. The first of these factors was as follows: ${ }^{70}$

... the reliance placed in some cases on commercial common sense and surrounding circumstances (eg in Chartbrook [2009] AC 1101, paras 16-26) should not be invoked to undervalue the importance of the language of the provision which is to be construed. The exercise of interpreting a provision involves identifying what the parties meant through the eyes of a reasonable reader, and, save perhaps in a very unusual case, that meaning is most obviously to be gleaned from the language of the provision. Unlike commercial common sense and the surrounding circumstances, the parties have control over the language they use in a contract.

Vos regards the words "save perhaps in a very unusual case" as "a nod to ICS" ${ }^{171}$ but reiterates his earlier point ${ }^{72}$ that "as later cases show, it would be surprising if ICS were to be decided in the same way today". ${ }^{73}$ The problem here is that the above factor is not at all inconsistent with the ICS principles. There can be no question that Lord Hoffmann accepted that the ordinary meaning of the language used by the parties is not lightly to be departed from. His Lordship stressed in his leading judgments that there will usually be no answer to the solution derived from giving the words their ordinary or conventional meaning because that is the meaning the document will convey to a
66 At [60].
67 At [76].
68 Rainy Sky, above n 9, at [28].
69 Arnold, above n 11, at [77] (emphasis added).
70 At [17]
71 Vos, above n 3, at 6.
72 At 2 .
73 At 6. 
reasonable person unless there is something in the background to suggest that something went wrong with the language and therefore that the parties might reasonably be taken to have intended a different meaning. Thus, his Lordship introduced his fifth ICS principle by conceding that the so-called "rule" that "words should be given their 'natural and ordinary meaning' reflects the common sense proposition that we do not easily accept that people have made linguistic mistakes, particularly in formal documents". ${ }^{74}$ And later in his dissenting judgment in Bank of Credit and Commerce International SA (in liq) $v$ Ali, ${ }^{75}$ where he criticised the majority for giving "too little weight to the actual language and background" of the document in question, ${ }^{76}$ he said that "the primary source for understanding what the parties meant is their language interpreted in accordance with conventional usage". ${ }^{77}$ Plainly, his Lordship was not a judge who would, willy-nilly, depart from the ordinary meaning of contractual language in order to achieve a fairer or more reasonable outcome. ${ }^{78}$

Lord Neuberger's second factor in Arnold v Britton states that: ${ }^{79}$

... when it comes to considering the centrally relevant words to be interpreted, I accept that the less clear they are, or, to put it another way, the worse their drafting, the more ready the court can properly be to depart from their natural meaning. That is simply the obverse of the sensible proposition that the clearer the natural meaning the more difficult it is to justify departing from it. However, that does not justify the court embarking on an exercise of searching for, let alone constructing, drafting infelicities in order to facilitate a departure from the natural meaning. If there is a specific error in the drafting, it may often have no relevance to the issue of interpretation which the court has to resolve.

Vos regards this factor as "directly in conflict" 80 with Lord Hoffmann's statement in his fifth ICS principle that: ${ }^{81}$

74 ICS, above n 2, at 913. See also his earlier seminal judgment in Mannai Investment, above n 22, at 774, where he said that "[w]e start with an assumption that people will use words and grammar in a conventional way".

75 Bank of Credit and Commerce International SA (in liq) v Ali [2001] UKHL 8, [2002] 1 AC 251.

76 At [37].

77 At [39].

78 See also the judgments of the Privy Council delivered by his Lordship in Board of Trustees of the National Provident Fund v Brierley Investments Ltd [1997] 1 NZLR 1 (PC) and Yoshimoto v Canterbury Golf International Ltd [2002] UKPC 40, [2004] 1 NZLR 1 where the plain meaning of the contracts in question was upheld. In the former case it was held that a term in an agreement to assign a lease that "the lease must not contain a ratchet clause" did not mean that the lease must not contain clauses having a ratchet effect, such as a clause providing for discretionary rent reviews, even though the consequence of this interpretation was to render the lease "hopelessly uneconomic" (at 5).

79 Arnold, above n 11, at [18].

80 Vos, above n 3, at 6.

81 ICS, above n 2, at 913. 
... if one would nevertheless conclude from the background that something must have gone wrong with the language, the law does not require judges to attribute to the parties an intention which they plainly could not have had.

He does so on the basis that, when Lord Neuberger said in the penultimate sentence of the above paragraph "that does not justify the court embarking on an exercise of searching for, let alone constructing, drafting infelicities", 82 his Lordship meant "that did not justify the court embarking on an exercise of searching for, let alone [correcting] ... drafting infelicities". ${ }^{83}$ In my view, however, the author's alteration of Lord Neuberger's statement is unfounded. His Lordship meant exactly what he said. He used the phrase "constructing drafting infelicities" in the sense of "making up", "inventing", or "fabricating" drafting infelicities. He meant that the court should not set out on a search for drafting infelicities, let alone make up or fabricate such infelicities. So read, the statement is uncontentious and it is unlikely that Lord Hoffmann would take issue with it.

Lord Neuberger's third factor is that "commercial common sense is not to be invoked retrospectively". ${ }^{84}$ It "is only relevant to the extent of how matters would or could have been perceived by the parties, or by reasonable people in the position of the parties, as at the date that the contract was made" ${ }^{85}$ Vos argues that this factor "again differs from" the fifth $I C S$ principle. ${ }^{86}$ However, it is hard to see why, particularly when that principle is read, as it must be, in the light of the fundamental first principle that: ${ }^{87}$

Interpretation is the ascertainment of the meaning which the document would convey to a reasonable person having all the background knowledge which would reasonably have been available to the parties in the situation in which they were at the time of the contract.

Vos also regards Lord Neuberger's fourth factor as "again somewhat at odds with Lord Hoffmann's approach". ${ }^{88}$ This factor concedes that "commercial common sense is a very important factor to take into account when interpreting a contract" 89 but subject to the qualification that: ${ }^{90}$

82 Arnold, above n 11, at [18] (emphasis added).

83 Vos, above n 3, at 6 (emphasis added).

84 Arnold, above n 11, at [19].

85 At [19].

86 Vos, above n 3, at 7.

87 ICS, above $\mathrm{n}$ 2, at 912 (emphasis added).

88 Vos, above n 3, at 7.

89 Arnold, above n 11, at [20].

90 At [20]. 


\begin{abstract}
... a court should be very slow to reject the natural meaning of a provision as correct simply because it appears to be a very imprudent term for one of the parties to have agreed, even ignoring the benefit of wisdom of hindsight. The purpose of interpretation is to identify what the parties have agreed, not what the court thinks that they should have agreed. Experience shows that it is by no means unknown for people to enter into arrangements which are ill-advised, even ignoring the benefit of wisdom of hindsight, and it is not the function of a court when interpreting an agreement to relieve a party from the consequences of his imprudence or poor advice. Accordingly, when interpreting a contract a judge should avoid re-writing it in an attempt to assist an unwise party or to penalise an astute party.
\end{abstract}

There is no inconsistency here with Lord Hoffmann's approach. His Lordship made exactly these points in Chartbrook. He there stressed that: ${ }^{91}$

... the fact that a contract may appear to be unduly favourable to one of the parties is not a sufficient reason for supposing that it does not mean what it says.

It may be that "a provision favourable to one side was ... in exchange for some concession elsewhere or simply a bad bargain". 92

Finally, Vos concedes that Lord Neuberger's sixth factor "included a further nod to ICS", albeit only "within a very limited compass". 93 This observation downplays the significance of the factor because it implicitly rejects the author's central thesis that the legal pendulum has now swung back to a position closely approximating the old plain meaning rule. Lord Neuberger said: ${ }^{94}$

Sixthly, in some cases, an event subsequently occurs which was plainly not intended or contemplated by the parties, judging from the language of their contract. In such a case, if it is clear what the parties would have intended, the court will give effect to that intention. An example of such a case is Aberdeen City Council v Stewart Milne Group Ltd 2012 SC (UKSC) 240, where the court concluded that "any ... approach" other than that which was adopted "would defeat the parties' clear objectives", but the conclusion was based on what the parties "had in mind when they entered into" the contract: see paras 21 and 22 .

The latter reference to what the parties "had in mind" is somewhat puzzling in view of his Lordship's earlier statement that the court must disregard "subjective evidence of any party's intentions". 95 However, in the context of the endorsement of their Lordships' decision in Aberdeen City Council v

91 Chartbrook, above n 19, at [20].

92 At [20].

93 Vos, above n 3, at 7.

94 Arnold, above n 11, at [22]

95 At [15]. 
Stewart Milne Group Ltd, ${ }^{96}$ it is likely that Lord Neuberger was referring to the parties' objectively determined common purpose. More importantly for present purposes, Aberdeen was a case where the plain meaning of the contract was displaced because it would defeat the purpose of the clause in question, and as a result it arguably contradicts Vos's thesis.

The dispute concerned a contract for the sale of land from the council to a development company that obliged the company to pay an uplift in the price in the event of an on sale in accordance with a formula based on the gross sale proceeds. The company sought to avoid this liability by transferring the land to another company within the same corporate group at a price that was far below its open market value and too low for the uplift to become payable. Nothing in the contract seemed to prohibit expressly what the company had done, but in the view of the Judges it was contrary to what the parties could reasonably be taken to have intended. Lord Hope (with whom Lady Hale, Lord Mance and Lord Kerr agreed) did not think that a finding for the council would do "undue violence"97 to the language the parties had used because their commercial purpose, readily apparent from the terms of the contract read as a whole, was that in the event of an on sale the uplift was to be calculated on the basis of the (assumed) market price obtained. In other words, although the language chosen was inapposite, it was evident that the parties contemplated an arm's-length sale at market value.

As I have discussed at greater length elsewhere, ${ }^{98}$ Lord Neuberger's approval of the decision in Aberdeen City Council points to an important distinction that he must have seen between the facts in that case and those in Arnold. The latter was a case where an apparently unreasonable consequence for one contracting party of the ordinary or "natural" meaning of the language of the contract arose from the occurrence of subsequent external events (subsequent falls in the annual rate of inflation), whereas in Aberdeen the unreasonable consequence was inherent from the outset in the language itself and the purchaser was seeking to take advantage of its literal meaning to gain a benefit that was objectively inconsistent with the purpose of the provision. The distinction between the two cases no doubt explains why his Lordship felt it necessary to stress the factors discussed above: most importantly, "commercial common sense is not to be invoked retrospectively"; 99 what the parties can reasonably be taken to have meant is to be determined in the light of the facts known, or reasonably available to them, at the time of the contract; and it is no part of the function of interpretation to remedy bad bargains. For the reasons discussed, Lord Hoffmann would not have disagreed with any of this.

96 Aberdeen City Council v Stewart Milne Group Ltd [2011] UKSC 56, 2012 SCLR 114.

97 At [22].

98 McLauchlan "Some fallacies concerning the law of contract interpretation", above n 1.

99 Arnold, above n 11, at [19]. 


\section{WHAT DID WOOD V CAPITA DECIDE?}

Vos argues that the "palpable change"100 in the law has been confirmed by the United Kingdom Supreme Court's most recent decision in Wood v Capita. ${ }^{101}$ In his view, the Court, in the judgment delivered by Lord Hodge, not only endorsed Rainy Sky and Arnold v Britton, "but did so in such a way as to make clear that there is no room in the current law for the fourth and fifth principles stated in $I C S " .{ }^{102} \mathrm{He}$ acknowledges that Lord Hodge said that "[t]he recent history of the common law of contractual interpretation is one of continuity rather than change", ${ }^{103}$ but he regards this as a "remarkable"104 statement, seemingly because it illustrates his earlier observation that "judges at the highest level have not always said exactly what they mean". ${ }^{105}$

My view, however, is that, particularly when Lord Hodge's judgment is read in light of his reasoning in Arnold v Britton, ${ }^{106}$ it is much more likely that he did mean exactly what he said. ${ }^{107}$ Most importantly, it is apparent from the following observations that he had not the slightest intention to cast doubt on, or qualify, any of the ICS principles. First, the judgments in Arnold v Britton, including that of Lord Carnwath (dissenting), "were saying the same thing"108 so far as the principles stated in Lord Hoffmann's "celebrated judgment"109 in ICS were concerned. Secondly, Arnold did not bring about "a recalibration of the approach summarised in Rainy Sky", ${ }^{110}$ an approach that Lord Hodge implicitly regarded as entirely consistent with the ICS principles. Thirdly, determining the

100 Vos, above n 3, at 2.

101 Wood v Capita, above n 12.

102 Vos, above n 3 , at 7.

103 Wood v Capita, above n 12, at [15].

104 Vos, above n 3, at 7.

105 At 2 .

106 See the main text following n 67 above.

107 In any event, a perusal of the numerous later English cases reveals that the judgment has been taken at face value. See for example Botleigh Grange Hotel Ltd v Her Majesty's Revenue and Customs [2018] EWCA Civ 1032 at [17]-[25]; Malone v Birmingham Community NHS Trust [2018] EWCA Civ 1376 at [19]-[20]; National Bank of Kazakhstan v The Bank of New York Mellon SA/NV, London Branch [2018] EWCA Civ 1390 at [37]-[38]; Council of the City of York v Trinity One (Leeds) Ltd [2018] EWCA Civ 1883 at [36]; Barnardo's v Buckinghamshire [2018] UKSC 55, [2019] 2 All ER 175 at [13]; British Telecommunications plc v BT Pension Scheme Trustees Ltd [2018] EWCA Civ 2694 at [12]; Hopkinson v Towergate Financial (Group) Ltd [2018] EWCA Civ 2744 at [16]; The State of the Netherlands v Deutsche Bank AG [2019] EWCA Civ 771 at [50] (judgment delivered by Sir Geoffrey Vos); Elite Property Holdings Ltd v Barclays Bank plc [2019] EWCA Civ 204 at [44]; and Pease v Henderson Administration Ltd [2019] EWCA Civ 158 at [49].

108 Wood v Capita, above n 12, at [14].

109 At [10].

110 At [9]. 
objective meaning of contractual language "is not a literalist exercise". ${ }^{111}$ It necessarily involves consideration of the whole contract and the relevant factual background, with the weight to be given to the latter "depending on the nature, formality and quality of drafting of the contract". ${ }^{112}$ Fourthly, interpretation is a "unitary exercise" so that "where there are rival meanings", the court can choose the one that is "more consistent with business common sense". ${ }^{113}$ However, "in striking a balance between the indications given by the language and the implications of the competing constructions", the court must bear in mind the possibilities that one of the parties has made a bad bargain or that "a provision may be a negotiated compromise or that the negotiators were not able to agree more precise terms". ${ }^{114}$ Fifthly, the unitary exercise necessarily involves an "iterative process". ${ }^{115}$ The rival interpretations must be checked against the other provisions of the contract and their commercial consequences investigated. Finally, "[t]extualism and contextualism are not conflicting paradigms in a battle for exclusive occupation of the field of contractual interpretation". ${ }^{116}$ Thus, the assistance that textual and contextual considerations will provide in determining objective meaning may vary according to the circumstances of the agreement in question. The context may be of greater assistance in the case of informal agreements prepared without professional advice than in the case of formal agreements prepared by "skilled professionals". ${ }^{117}$ Nevertheless, the iterative process must be applied in both scenarios because even the "negotiators of complex formal contracts may often not achieve a logical and coherent text". ${ }^{118}$ This may be because the parties had conflicting objectives, they failed to communicate clearly with each other, they employed different drafting practices, or there were deadlines requiring them to compromise in order to conclude the contract.

The above observations are consistent with the $I C S$ principles $^{119}$ and so too is the actual decision in Wood v Capita, even though it was held that the objective meaning of the disputed term was "to be

111 At [10].

112 At [10].

113 At [11].

114 At [11].

115 At [12].

116 At [13].

117 At [13].

118 At [13].

119 It is worth noting too that Lord Hodge expressly agreed (at [25]) with the reasoning in the judgment of the Court of Appeal delivered by Christopher Clarke LJ (Wood v Sureterm Direct Ltd \& Capita Insurance Services Ltd [2015] EWCA Civ 839). In that judgment his Lordship endorsed, inter alia, the first ICS principle, the unitary nature of the task of interpretation, and the need for caution in applying considerations of business common sense, particularly since what seems from one party's perspective to be contrary to business common sense may sometimes be "the product of a compromise which was the only means of reaching agreement" (at [29]) or simply the result of a bad bargain (at [30]). His Lordship then observed (at [31]): 
found principally in a careful examination of the language which the parties have used". ${ }^{120}$ The case involved "a detailed and professionally drafted contract"121 between "commercially sophisticated" parties $^{122}$ where the result of that examination in the light of the other terms of the contract and the commercial context did not reveal any consequences that were anomalous or "contrary to business common sense". ${ }^{123}$ Nothing had gone so significantly wrong with the language as to suggest that a reasonable person with knowledge of the background would give the contract a meaning different from that derived from its textual analysis. The appellant had, in hindsight, made a bad bargain. Therefore the case illustrates the point we have seen Lord Hoffmann made on several occasions that there will usually be no answer to the solution derived from giving the language its ordinary or conventional meaning.

\section{CONCLUSION}

Vos concluded his article by observing that the debate concerning the principles of contract interpretation "is certainly not over, but we have just perhaps concluded one swing of the

In effect a balance has to be struck between the indications given by the language and the implications of rival constructions. The clearer the language the less appropriate it may be to construe or confine it so as to avoid a result which could be characterised as unbusinesslike. The more unbusinesslike or unreasonable the result of any given interpretation the more the court may favour a possible interpretation which does not produce such a result and the clearer the words must be to lead to that result. Thus if what is prima facie the natural reading produces a wholly unbusinesslike result, the court may favour another, even if less obvious, reading. But, as Lord Neuberger observed in Arnold $v$ Britton at [17] "commercial common sense and surrounding circumstances ... should not be invoked to undervalue the importance of the language of the provision which is to be construed."

120 Wood v Capita, above n 12, at [42].

121 At [16].

122 At [28].

123 At [40]. In brief, Capita bought from Wood an insurance broking company, Sureterm, that specialised in arranging insurance for classic cars. As mentioned in the text, both parties were commercially sophisticated. They were also experienced in the insurance broking industry. After completion of the sale, Capita discovered that Sureterm had mis-sold insurance to customers. They were obliged to inform the Financial Services Authority and in due course agreed to put in place a remediation scheme to compensate customers who might have been affected. They later sought to recover their losses from Wood under an indemnity clause in the sale contract that Lord Hodge described as "avoidably opaque" (at [26]). Nevertheless, his Lordship's careful textual analysis of the clause convincingly showed that the indemnity was only triggered in the event of claims or complaints by Sureterm's customers. This "might have appeared anomalous" (at [40]) were it not for the fact that the schedule to the contract of sale contained wide-ranging warranties that would have protected Capita in the circumstances that eventuated provided Sureterm's regulatory breaches were uncovered and notified within two years of completion. This was "not an unreasonable time scale" (at [40]) but Capita had not complied with it. Accordingly, Lord Hodge concluded at [40] that it was:

... not contrary to business common sense for the parties to agree wide-ranging warranties, which are subject to a time limit, and in addition to agree a further indemnity, which is not subject to any such limit but is triggered only in limited circumstances. 
pendulum". ${ }^{124}$ However, for the reasons discussed, the argument that there has been a palpable swing back to something approaching the traditional approach, which first and foremost focussed on whether the rival interpretations were "available meanings" of the words in question, is unconvincing. In my view, the decisions of the United Kingdom Supreme Court that have been discussed are for the most part best viewed as spelling out what was either explicit or implicit in the ICS principles in the first place. Undoubtedly, the principles will continue to be contentious, particularly among commercial practitioners who like to think that they should be able to give reliable advice as to the true interpretation of contracts crossing their desks simply by pondering the words in question and, if need be, consulting their dictionaries. They reside in: ${ }^{125}$

... that lawyer's Paradise ... where, if the writer has been careful, a lawyer, having a document referred to him, may sit in his chair, inspect the text, and answer all questions without raising his eyes.

They, as well as commentators who are hostile to the principles on the basis of their primitive belief in the inherent and unbending meaning of words, are inclined to fasten on judicial dicta, often taken out of context, as spelling the demise of ICS. Rather more measured commentators have carried the day. In this respect it is worth noting that in Wood $v$ Capita Lord Hodge singled out ${ }^{126}$ the extrajudicial contribution of the great commercial judge, Lord Bingham. ${ }^{127}$ In the course of his article $\mathrm{e}^{128}$ Lord Bingham endorsed the view of Arden LJ in Static Control Components (Europe) Ltd v Egan ${ }^{129}$ that "the principles in the ICS case lead to a more principled and fairer result by focussing on the meaning which the relevant background objectively assessed indicates that the parties intended"130 and added: ${ }^{131}$

Notable for its absence in the criticisms made of the ICS formulation is the one accusation which, if established, would be truly damaging: that application of this approach leads to a construction of contractual documents which does not reflect the commercial intentions of the parties. Unless that criticism can be made and brought home, it would need compelling arguments to displace the current approach to the task of seeking to give effect to the reasonable expectations of honest men.

124 Vos, above n 3, at 13

125 James Bradley Thayer A Preliminary Treatise on Evidence at the Common Law (Little, Brown and Co, Boston, 1898) at 428-429.

126 Wood v Capita, above n 12, at [10].

127 Lord Bingham of Cornhill "A New Thing under the Sun? The Interpretation of Contract and the ICS Decision" (2008) 12 Edinburgh L Rev 374.

128 At 387.

129 Static Control Components (Europe) Ltd v Egan [2004] EWCA Civ 392, [2004] 2 Lloyd's Rep 429 at [29].

130 Bingham, above n 127, at 387-388.

131 At $387-388$ 
Lord Bingham also questioned whether the "highly desirable goal" of certainty of interpretation in commercial transactions is more likely "to be promoted by giving a rather literal meaning to the language used" than by giving it "a meaning which reasonable commercial parties, placed as they were and knowing what they did, would be [likely] to have intended"132 and he concluded: ${ }^{133}$

The closer the courts can approach to [the latter] meaning, generally speaking, the more certain the likely outcome, since this is a meaning which should reflect the reasonable expectations of honest men and be as readily perceived by a party and his legal advisers as by a judge.

More importantly, however, and contrary to the views of Vos and other commentators, ${ }^{134}$ the law is now clear in the following critical respects. First, as stated by Lord Hoffmann in his first ICS principle, which no court has questioned in recent times, the task of interpretation involves the ascertainment of the meaning that the document would convey to a reasonable person with knowledge of the factual background. This principle is inconsistent with the existence of a plain meaning rule because, as we have seen, it not only allows but requires consideration of the background to the contract as part of the unitary task of interpretation, regardless of whether there is any perceived ambiguity.

Secondly, since interpretation disputes are heavily fact specific, the meaning that will be conveyed to a reasonable person will depend on a wide variety of factors, including: the clarity of the language in dispute; the formality of the document and the quality of its drafting; the nature of the contract; the genesis and purpose of the transaction; other admissible aspects of the factual background that were known, or ought to have been known, to the parties; and the consequences of the rival contentions. With regard to the latter factor, in L Schuler AGv Wickman Machine Tool Sales Ltd Lord Reid said, in a well-known passage that was endorsed in Rainy Sky: ${ }^{135}$

The fact that a particular construction leads to a very unreasonable result must be a relevant consideration.

The more unreasonable the result the more unlikely it is that the parties can have intended it, and if they

do intend it the more necessary it is that they shall make their intention abundantly clear.

Thus, the degree of required unreasonableness should be assessed with reference to the degree of clarity of the words in dispute.

132 At 388

133 At 388-389.

134 See generally McLauchlan "Some fallacies concerning the law of contract interpretation", above n 1.

135 L Schuler AG v Wickman Machine Tool Sales Ltd [1974] AC 235 (HL) at 251, as quoted in Rainy Sky (SC), above $\mathrm{n} 9$, at [16]. 
Thirdly, as Lord Hodge reminded us in Wood $v$ Capita, ${ }^{136}$ a further corollary of the first ICS principle is that the interpretative task requires a careful balancing of internal textual considerations and external factors. The fact that the language of the text clearly supports the position of one of the parties will be important, indeed usually decisive, but it cannot be conclusive in all cases of what the reasonable person would understand them to have meant. The language may contain an obvious typing mistake. Or, as in ICS, the drafting may be "slovenly" yet "tolerably clear"137 but give rise to consequences that, although they "cannot be regarded as 'ridiculous' or 'extraordinary' or 'very unreasonable"', 138 are sufficiently anomalous or "uncommercial" to justify a conclusion that a reasonable person would not regard the language as meaning what it appears to say. ${ }^{139}$ In other words, a mere unreasonable result may, when all circumstances are considered, suffice to displace a literal meaning. ${ }^{140}$ On the other hand, to take an example at the other end of the spectrum, in the case of a formal and fully negotiated contract where the language in dispute, read in the context of the whole document, has only one meaning according to ordinary usage, it will usually be difficult to displace that meaning unless the consequence is so absurd or irrational that it cannot possibly have been intended. This is because, in the absence of such a consequence, it is the meaning that would be conveyed to a reasonable person with knowledge of the background.

Of course, it is a regular occurrence for judges to disagree on the outcome of interpretation disputes, but this will often be because they balance textual and external considerations differently. And, as we have seen, this largely explains the disagreement between the Court of Appeal and the Supreme Court in the much misunderstood case of Rainy Sky. Thus, in the Court of Appeal Patten LJ's view that the language of the bond was relatively clear led him to insist on the need for the buyers to establish something akin to an absurd or irrational result of the bank's interpretation, because only then would a reasonable person reject that interpretation. On the other hand, Lord Clarke's view in the Supreme Court was that the competing textual arguments were finely balanced, and this enabled him

136 See the main text above at n 116. See also, for a useful discussion of the balancing exercise, Ryan Catterwell "Striking a Balance in Contract Interpretation: The Primacy of the Text" (2019) 23 Edinburgh L Rev 52. As the author points out (at 53) "the correct interpretation is chosen by weighing and balancing the competing considerations to arrive at the probable intention of the parties. Hence, although a sequential process, construction is a 'unitary' exercise: all of the competing factors are evaluated at once to determine the correct interpretation."

137 ICS, above n 2, at 899 per Lord Lloyd.

138 At 905 per Lord Lloyd.

139 "[T]he poorer the quality of the drafting, the less willing any court should be to be driven by semantic niceties to attribute to the parties an improbable and unbusinesslike intention": Mitsui Construction Co Ltd v AttorneyGeneral of Hong Kong [1986] LRC (Comm) 245 (PC) at 253 per Lord Bridge, part of a passage endorsed by Mance LJ in Gan Insurance Co Ltd v Tai Ping Insurance Co Ltd (No 2) [2001] EWCA Civ 1047, [2001] CLC 1103 at [13], which was in turn approved by Lord Clarke in Rainy Sky (SC), above n 9, at [26].

140 Although debate on the issue is somewhat sterile, this is why I disagree with Vos, above n 3, at 2 and 6, that, if the facts of ICS arose again today, the case would have to be decided differently. 
to uphold the buyers' interpretation on the basis that the reasonable person would have understood the parties to have meant what was more consistent with business common sense.

Finally, even when the consequence of an interpretation based on textual considerations does appear absurd, it is important, as mentioned earlier, to bear in mind Lord Hoffmann's caution in Chartbrook that: ${ }^{141}$

... the fact that a contract may appear to be unduly favourable to one of the parties is not a sufficient reason for supposing that it does not mean what it says.

This is because even experienced business people sometimes make binding agreements that might be seen as making no commercial sense without there being any real question that the agreements do not mean what they appear to say. Interpretation is about working out what the parties agreed, actually or objectively, and the fact that no person in the position of one of the parties acting rationally would have entered into the agreement if it had a particular meaning does not always provide a basis for arguing that something else must have been intended. Of course, distinguishing between an unduly favourable bargain and a commercially absurd bargain that was not intended is no easy task. However, it is also important to bear in mind that in the leading House of Lords' cases of Mannai, ICS and Chartbrook, in each of which an interpretation was accepted that appeared contrary to the conventional meaning of the words in question, their Lordships were satisfied that there had been a linguistic mistake and that a reasonable person with knowledge of the background would have given the words a different meaning. Thus, in Chartbrook it was stressed that "the striking feature" of the case was not simply that the interpretation adopted by the lower courts was favourable to the respondent (Chartbrook) but that it made: ${ }^{142}$

... the structure and language of the various provisions ... appear arbitrary and irrational, when it is

possible for the concepts employed by the parties ... to be combined in a rational way.

In their Lordships' view, it was "clear that something ha[d] gone wrong with the language" and "clear what a reasonable person would have understood the parties to have meant". ${ }^{143}$

141 Chartbrook, above n 19, at [20].

142 At [20].

143 At [25]. 